\title{
Meet the 2021 Congressional Fellows
}

\section{NATHANIEL BADER | ASSOCIATE, CONGRESSIONAL FELLOWSHIP PROGRAM}

Olivia Garcia, PhD is currently an American Political Science Association (APSA) 2021 2022 Congressional Fellow and received the honor of a William A. Steiger Fund for Legislative Studies. Prior to receiving the prestigious APSA fellowship, Dr. Garcia served as the public poli-

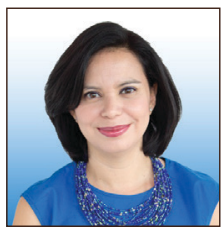
cy and training manager with Casa de Esperan-

za: National Latin@ Network. She brings with her a background in advocacy, training and research related to gender-based violence that spans 10 years. Dr. Garcia completed her doctorate in Political Science from UCLA with an emphasis on Race and Ethnicity Politics, Gender Studies and Political Theory. Her research focuses on the Violence Against Women Act and the ways in which the theory of intersectionality is absent from policy, although it is a necessary consideration when on-the-ground advocates are helping survivors of intimate partner violence. Before joining Casa de Esperanza: National Latin@ Network, Dr. Garcia worked as the Underserved Populations Director for the National Center for Victims of Crime. Dr. Garcia is an affiliate faculty member for the University of Texas at El Paso's Criminal Justice and Chicano Studies Departments since 2016. She has taught American Government and Texas Government at the El Paso Community College District since 2005.

Sebastian Garcia received his Juris Doctor degree from Vermont Law School in 2019 and his Master of Laws (LLM) in Space, Cyber, and Telecommunications Law from the University of Nebraska-Lincoln in 2021. His research focuses on cybersecurity law and policy, international comparative law, and telecommunications policy.

Thomas Gray is an assistant professor of political science in the School of Economic, Political and Policy Sciences at the University of Texas at Dallas. He teaches courses on American politics and American civil rights and liberties. He researches questions of American political institutions, especially Congress and state judicial

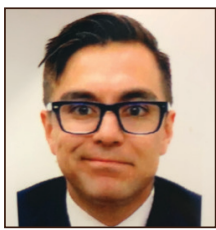
politics. For example, to complete his dissertation, he extensively researched the impact that reappointment has on state supreme court justice behavior. In the last several years, he has published articles in a variety of political science journals across a range of topics in American politics. After growing up in Maryland, he received his BA (political science) from the University of Maryland - College Park. He then received his J.D. from Western New England University and his MA and PhD from the University of Virginia. In his private time, he is an avid sports fan and enjoys traveling to see matches of the biggest soccer clubs in the world.

Lauren M. Poteat is an award-winning author and journalist, who currently reports within the Washington DC area. Working for media outlets including Prince George's Community Television Station, AFRO American Newspapers and the Washington Informer, in 2018, Lauren was honored with the prestigious Society of Pro-

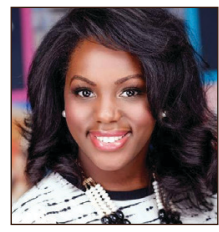
fessional Journalists 'Dateline Award' for her work coverage on Capitol Hill. In 2020, Lauren Poteat self-published her debut children's book Giraffes Don't Talk To Ants, and in 2021, was honored with a children's book award from the New York Book Festival. In addition to media and writing, Lauren Poteat is also highly active in her community and currently serves as a Board Member to the National Council of Negro Women, board member to the Washington School for Girls and Political Action Committee Chair for the Washington DC Branch of the NAACP. In 2021, she was also awarded with a Proclamation from the Governor of Maryland for her leadership and service.

Katherine Rader is a political scientist specializing in American political development, political economy, race, and labor politics. For the 2021-2022 academic year, she will be in Washington DC as part of the APSA Congressional Fellowship Program. In the fall of 2022, she will be

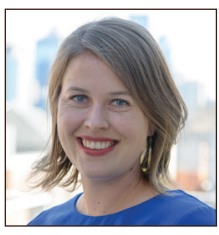
starting as an assistant professor in the Department of Political Science at Christopher Newport University. Her current research asks how coalitions that formed to fight for both racial and economic justice in the early twentieth-century shifted their focus away from programs for economic redistribution. Instead, they pursued a version of anti-discrimination politics that failed to challenge legislation in the 1940s-1960s that chipped away at labor rights and social welfare programs. Katherine completed her $\mathrm{PhD}$ in political science at the University of Pennsylvania in 2021, where she also served as a Graduate Fellow in the Andrea Mitchell Center for the Study of Democracy in 2020-2021. Prior to starting her doctoral program at Penn, she worked in health policy and nonprofit governance in Washington DC for five years. Before that, she earned a BA in Politics \& Government from the University of Puget Sound.

Beatriz Rey is a NSF Agora Visiting Fellow at Johns Hopkins University. She studies legislative politics in a comparative perspective. In particular, her current work focuses on legislative effectiveness in Brazil and the United States. She holds a PhD in political Science from Syracuse University and a MA in political science from the University of North Carolina at Chapel Hill.

Kathleen Rogers received her doctoral education in political science at Rutgers University. Her research examines opportunities for and challenges to women's political inclusion-both as elected officials and as citizens-in the United States. Her dissertation, which was supported by an AAUW American Fellowship, provides a new framework for understanding the relationship between women's political representation and civic engagement through the mechanism of emotions, such as anger, fear, and enthusiasm. She also holds an MA in political science and a graduate certificate in women's and gender studies from Rutgers as well as a BA from Muhlenberg College.

Austin Weinstein is a financial journalist who has covered banking and mortgage policy, among other topics. He was previously the banking reporter at The Charlotte Observer, and a reporter at Bloomberg News. He received a BA in history from the University of California, Berkeley.
